\title{
Effect of microbially induced calcite precipitation on soil thermal conductivity
}

\author{
S. VENULEO*, L. LALOUI*, D. TERZIS*, T. HUECKEL $\uparrow$ and M. HASSAN $*$
}

\begin{abstract}
Efficiency of energy piles is strongly affected by soil saturation conditions: low water contents considerably decrease their performance thus limiting the possibility to extend their application to arid environments. This paper investigates the microbially induced calcite precipitation (MICP) technique as a potential means of enhancing the soil-pile heat exchange rates by improving the thermal properties of soil. The study puts the focus on measuring the thermal conductivity of untreated and treaded sand at various degrees of saturation. Experimental results clearly show a significant improvement of the thermal conductivity of soil especially for low degrees of saturation. This enhancement is attributed to the mineralised calcite crystals acting as 'thermal bridges' between the soil grains, offering a larger surface area for heat exchange compared with the untreated material in which exchanges occur through smaller contact points.
\end{abstract}

\section{KEYWORDS:}

ICE Publishing: all rights reserved

\section{INTRODUCTION}

Energy piles used as ground heat exchangers take advantage of the high thermal storage capacity of soil and have come to be seen as a cost-efficient, reliable and environmentalfriendly technology that is spreading rapidly throughout the world (Laloui \& Di Donna, 2011, 2013; Amatya, et al., 2012; Akrouch et al., 2015). The technology has met successful implementation in temperate climate zones, remains yet unexploited in hot, arid environments where the regional climatic conditions limit its possible advantages. Indeed, the air temperature, poor rainfalls and high evapotranspiration rates of these areas result in poor natural recharge of underground water and low saturation conditions, which alone can negatively affect the overall thermal properties of soil and thus the overall efficiency of energy piles. In particular, the decreasing heat storage capacity of soils as a result of soil desaturation, caused by the arid climate needs to be addressed to make energy piles a viable technology for hot areas.

This paper brings into focus the microbially induced calcite precipitation (MICP) technique as a potential solution for enhancing the thermal properties of soil for low saturation conditions. MICP is a biologically mediated method to induce in-situ cementation of granular soils (Mortensen \& DeJong, 2011; Fauriel \& Laloui, 2012) through the bacteria-driven urea hydrolysis, which in a calcium-rich environment results in calcium carbonate $\left(\mathrm{CaCO}_{3}\right)$ precipitation. So far the technique has been considered from a geotechnical point of view, solely to enhance the mechanical properties of soil (Whiffin et al., 2007; Harkes et al., 2009; Mortensen \& DeJong, 2011; De Jong et al., 2013). The increased strength and stiffness of

Manuscript received 19 August 2015; first decision 13 November 2015; accepted 11 December 2015.

Published online at www.geotechniqueletters.com on 00 Month 0000.

*Laboratory for Soil Mechanics, Swiss Federal Institute of Technology (EPFL), Lausanne, Switzerland.

†Department of Civil \& Environmental Engineering, Duke University, Durham, NC, USA.

†FCIT, King Abdulaziz University, Jeddah, Saudi Arabia. bio-cemented soils allow considering them even as construction materials (Bernardi et al., 2014). The bio-cementation of soils has been mainly addressed at laboratory scale rather than in real-field applications. Van Paassen et al. (2009) provided evidence that supports the feasibility of the technique at a large scale for cementing bigger soil volumes. The main advantage of the technique lies in the low viscosity of the treatment solutions used, which facilitates the circulation of the reactants in a targeted area without causing erosion of the in-situ soil. In this framework, the effect of MICP on the thermal properties of soils is investigated, postulating that the propagation of the bacterial and reactant solutions is feasible at targeted zones. The goal of this paper is to elucidate the contribution of calcite precipitation to the increase in soil thermal conductivity $(\lambda)$.

Numerical and experimental studies (Choi et al., 2011; Akrouch et al., 2015) have shown that under dry conditions the heat exchange may be reduced by up to $40 \%$ compared with that in fully saturated conditions. It is postulated here to compensate such reduction by inducing MICP, and hence altering the structural make-up of the soil; by the formation of intergranular calcite bridges, it is possible to increase the overall thermal connectivity of the solid matrix of the soil, and hence thermal conductivity. Soil thermal conductivity, as understood here, is the thermal conductivity of a multicomponent medium composed of variable volume fractions of all the soil phases: air, water and solid. Several structural Q3 factors influence the apparent conductivity, $\lambda$ : water content, mineral composition, bulk density, porosity and temperature (Becker et al., 1992; Lu et al., 2007; Wu et al., 2014). MICP affects all the above factors, in particular, porosity, soil mineral composition and the average soil dry density. The latter increases with the amount of precipitated calcium carbonate mass (Whiffin et al., 2007) and this increase is considered to reflect on the thermal conductivity of the treated soil, provided $\lambda$ increases linearly with dry density (Yun \& Santamarina, 2007).

The aim of this study is to validate this assumption by measuring and comparing the apparent thermal conductivity of untreated and MICP-treated sand samples at different degrees of saturation. Experimental observations (Farouki, 1981; Coté \& Konrad, 2005; Smits et al., 2009; 
Likos, 2014) suggest that the rate of change of thermal conductivity, with respect to saturation $S$, varies depending on the saturation regime. Three saturation regimes have been identified: the pendular regime $(S \leq 0 \cdot 2)$ characterised by the substantial variation in $\lambda$ with respect to $S$; the funicular regime $(0 \cdot 2 \leq S \leq 0 \cdot 9)$, characterised by mild $\lambda$ changes and the capillary regime $(S \geq 0 \cdot 9)$ characterised by no significant $\lambda$ changes (Smits et al., 2009, 2010; Likos, 2014). The authors will follow this classification.

\section{EXPERIMENTAL DETAILS}

\section{Materials and sample preparation}

Thermal conductivity of untreated sand specimens is measured and compared with that of an MICP-treated sample at different degrees of saturation. The tested material is pure silica sand (Itterbeck, Smals, the Netherlands)

Q4 classified as SP (USCS ASTM 2487) with properties as shown in Table 1. Untreated sand samples are prepared in a plastic case under five-layer wet compaction to different degrees of saturation. The target dry density value is chosen to be equal to that of the sample to be subjected to MICP, prior to performing the injections. This choice allows comparing the pre- and post-treatment thermal properties once the MICP technique has been applied and the change

Q5 has been evaluated. Details of the untreated samples and the plastic case are specified in Table 1.

To obtain the MICP-cemented sample, the bacteria strain Sporosarcina pasteurii (strain designation ATCC 11859) is grown under sterile conditions according to the protocol provided by the supplier (ATCC medium: 1376). The culture medium is centrifuged at $4000 \mathrm{~g}$ to harvest vegetative cells from the consumed nutrients. The harvested culture has

Q6 a cell concentration of $10^{8}$ colony-forming unit per $\mathrm{ml}$ $(\mathrm{cfu} / \mathrm{ml})$. Cells are subsequently resuspended in $0 \cdot 1 \mathrm{M}$ calcium chloride $\left(\mathrm{CaCl}_{2}\right)$ solution and injected in batches alternatively at the top and the bottom end of a prepacked Itterbeck sand column with an initial dry density equal to $1.68 \mathrm{~g} / \mathrm{cm}^{3}$. Bacteria are allowed an $8 \mathrm{~h}$ period to attach before introducing the urea- and calcium-rich solutions alternatively from the top and bottom of the column. Table 2 summarises the composition of solutions and the injection scheme.

Table 1. Sand, case and untreated sample properties

\begin{tabular}{l|l}
\hline Untreated sand properties & \\
Grain density: $\mathrm{g} / \mathrm{cm}^{3}$ & $2 \cdot 65$ \\
$C_{\mathrm{U}}$ & $2 \cdot 1$ \\
$C_{\mathrm{C}}$ & $0 \cdot 86$ \\
$D_{10}: \mathrm{mm}$ & $0 \cdot 1$ \\
$D_{50}: \mathrm{mm}$ & $0 \cdot 19$ \\
Silicon dioxide: \% & $>98$ \\
Dry density, $\rho_{\mathrm{d}}: \mathrm{g} / \mathrm{cm}^{3}$ & $1 \cdot 68$ \\
Porosity, $n$ & $0 \cdot 37$ \\
Void ratio, $e$ & $0 \cdot 58$ \\
Case dimensions & \\
Case height: $\mathrm{mm}$ & $88 \cdot 4$ \\
Case diameter: $\mathrm{mm}$ & $97 \cdot 8$ \\
\hline
\end{tabular}

The calcium carbonate precipitation is responsible for the cementation of sample with the precipitated nuclei filling the pores among the soil grains. The distribution of the calcium carbonate content inside the bio-cemented sample is measured across a section of the sample according to ASTM designation: D4373-14 (ASTM, n.d.) for 20 points in total. The properties of the obtained MICP-treated sample are listed in Table 3. To place the thermocouples in the bio-treated sample, two holes were opened using an electric screwdriver.

\section{Measuring device and methods}

Alrtimi et al. (2014) proposed a laboratory test to measure the thermal conductivity of soils based on Fourier's law of one-dimensional heat conduction at steady-state condition. They suggest that even though transient state procedures are simpler, the steady-state ones are considered more accurate. The proposed set-up is based on the guarded hot plate apparatus (GHPA) that is widely accepted as a primary apparatus to determine the apparent thermal conductivity (Xamàn et al., 2009). A similar GHPA set-up is used in this study. The device (Fig. 1) includes two plates - both connected to an independent temperature-control system responsible for maintaining the temperature constant on the boundaries of the tested sample, on its upper and bottom surfaces. The heat that flows longitudinally through the sample is independent of time. A thermal jacket is placed around the sample that serves as a heat insulation barrier. The two temperatures here referred to as $T_{\text {up plate }}$ and $T_{\text {down_plate }}$ have been, respectively, set to 35 and $20^{\circ} \mathrm{C}$. A heat flux sensor device connected to a voltage reader measuring instrument is put on the lower plate and the sample is placed above it. Provided that the heat flux $Q$ is longitudinal, the sensor measures the heat flux $Q / A$ across the sample according to relation (1) given by the manufacturer

$$
C \times \text { measured voltage }(\mathrm{mV})=\frac{Q}{A}\left(\frac{W}{m^{2}}\right)
$$

Finally, two thermocouples are placed at the two extremities of the sample, separated at distance $L$ from each other and connected to a software system that records the temperature variation with respect to time. With reference to this scheme, in steady-state conditions, $\lambda$ is computed as

$$
\lambda=\frac{Q}{A} \frac{L}{\left(T_{\text {down }}-T_{\text {top }}\right)}
$$

On the basis of device specifications and the accuracy of its components, an error range is calculated for the parameters affecting the $\lambda$ value. The obtained results concerning the untreated sand are validated using the empirical model of Coté \& Konrad (2005). The value of the degree of saturation corresponding to each measurement of the thermal conductivity is determined at the end of the test, once the steady state is reached (approximately after $3 \mathrm{~h}$ ). No data precisely corresponding to a fully saturated state are reported mainly due to the water leakage

Table 2. Composition and injection method of cementation solution used for the MICP treatment

\begin{tabular}{l|c|c|c|c|c|c|c}
\hline Urea & $\begin{array}{c}\text { Calcium } \\
\text { chloride }\end{array}$ & $\begin{array}{c}\text { Nutrient } \\
\text { broth }\end{array}$ & $\begin{array}{c}\text { Ammonium } \\
\text { chloride }\end{array}$ & $\begin{array}{c}\text { Number of } \\
\text { batches }\end{array}$ & $\begin{array}{c}\text { Input } \\
\text { rate }\end{array}$ & $\begin{array}{c}\text { Injection } \\
\text { point }\end{array}$ & $\begin{array}{c}\text { Period between } \\
\text { batches }\end{array}$ \\
\hline $0 \cdot 25 \mathrm{M}$ & $0 \cdot 25 \mathrm{M}$ & $3 \mathrm{~g} / \mathrm{l}$ & $10 \mathrm{~g} / 1$ & 16 & $5 \mathrm{ml} / \mathrm{min}$ & $\begin{array}{c}\text { Alternatively } \\
\text { top/bottom }\end{array}$ & $24 \mathrm{~h}$ \\
\hline
\end{tabular}


Table 3. Treated sample properties

MICP-treated sample properties

\begin{tabular}{l|r}
\hline Average calcium carbonate content: $\mathrm{g} / \mathrm{cm}^{3}$ & $0 \cdot 13$ \\
Diameter: mm & $57 \cdot 40$ \\
Height: mm & $75 \cdot 97$ \\
Diameter of the holes: mm & $3 \cdot 30$ \\
Depth of the holes: mm & 14 \\
Initial dry weight: $\mathrm{g}$ & 355.94 \\
Dry density: $\mathrm{g} / \mathrm{cm}^{3}$ & $1 \cdot 81$ \\
\hline
\end{tabular}

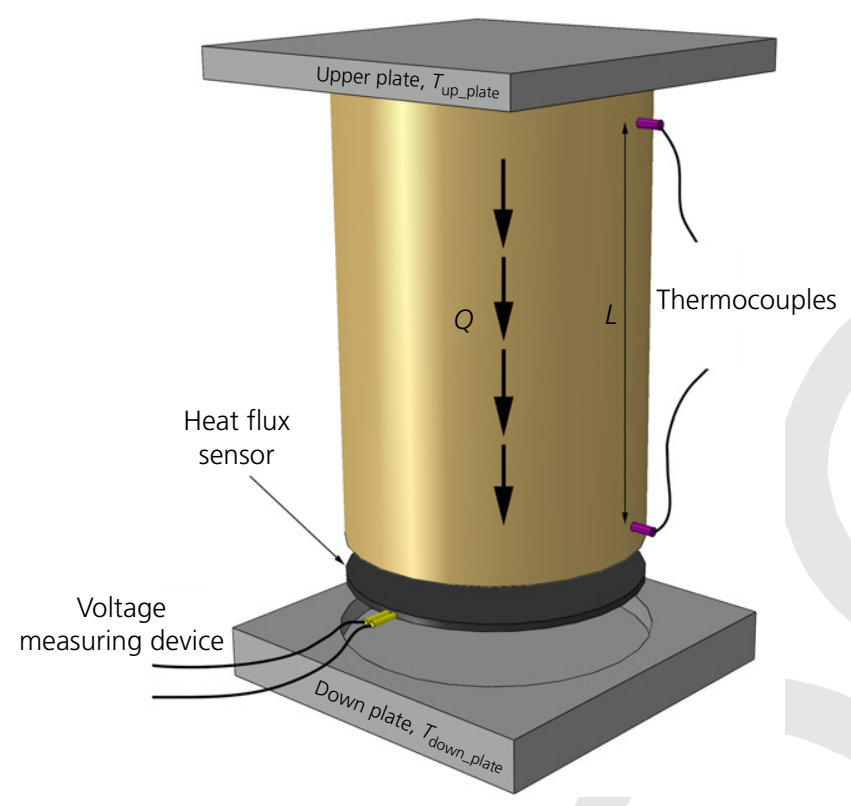

Fig. 1. (a) Schematic configuration of the measuring system

observed during sample preparation and also due to an expected evaporation during the test until the steady state is Q7 attained.

Through MICP a new mineral phase is formed inside the solid matrix, namely that of calcite. Scanning electron microscopy (SEM) is used to obtain an understanding of the fabric characteristics of the treated material.

\section{EXPERIMENTAL RESULTS AND DISCUSSION}

Figure 2 summarises the results obtained for the $\lambda$ values with respect to the degree of saturation for the untreated and MICP-treated Itterbeck sand. As expected, the thermal conductivity values increase with an increasing degree of saturation $S$. Moreover, the obtained results are found to reproduce the general trend of the three saturation regimes described in the introduction section. The average obtained value of $\lambda_{\text {dry }}$ (corresponding to $S=0$ ) is found to be equal to $0.30 \mathrm{~W} / \mathrm{mK}$. This value is in agreement with the Johansen (1975) and Lu et al. (2007) models that give $\lambda_{\text {dry }}=0 \cdot 27$ and $0.30 \mathrm{~W} / \mathrm{mK}$, respectively. However, provided that $\lambda$ within the capillary regime is often equal or close to $\lambda_{\text {sat }}$ (Smits et al., 2009; Likos, 2014), the value of thermal conductivity obtained for a degree of saturation equal to $88 \%$ $\left(\lambda_{88 \%}=2 \cdot 54 \mathrm{~W} / \mathrm{mK}\right)$ can be considered close to the $\lambda$ value at saturation $\left(\lambda_{\text {sat }}\right)$ and can be compared with the value obtained according to the model of Johansen (1975): $\lambda_{\text {satJ }}=2 \cdot 56 \mathrm{~W} / \mathrm{mK}$.

Table 4 summarises the standard deviation between the obtained values for the untreated material and those

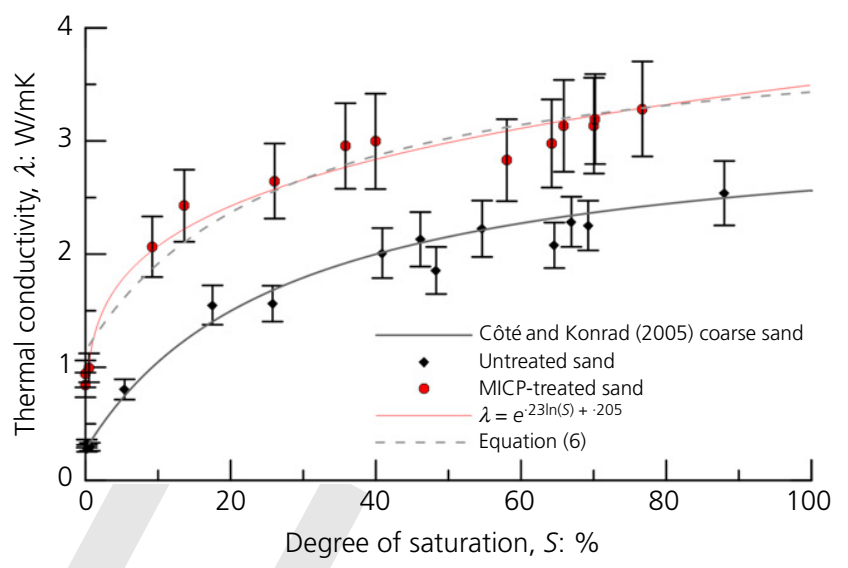

Fig. 2. Comparison between thermal conductivity of the MICP-treated and untreated sand

Table 4. Standard deviation of the obtained data for the untreated sand with respect to values predicted by models

\begin{tabular}{l|c}
\hline Model & Standard deviation \\
\hline Coté \& Konrad (2005) fine sand & $0 \cdot 016$ \\
Coté \& Konrad (2005) coarse sand & $0 \cdot 014$ \\
Lu et al. (2007) & $0 \cdot 033$ \\
Johansen (1975) & $0 \cdot 753$ \\
Square root model & $0 \cdot 029$ \\
Hu et al. (2001) & $0 \cdot 111$ \\
\hline
\end{tabular}

predicted by several semi-empirical models expressing $\lambda$ as a function of $S$. Each of these models uses different fitting parameters. Results were compared with the models of Johansen (1975), Hu et al. (2001), Coté \& Konrad (2005), $\mathrm{Lu}$ et al. (2007) and the square-root model. In particular, a good agreement is found with the models developed by Coté \& Konrad (2005) and Lu et al. (2007). Having the lowest standard deviation, this latter model for coarse sand has been found to be the best to fit the measures proposed by authors.

The semi-empirical models used for comparison with the obtained $\lambda$ values were based on the formulation offered by Johansen (1975)

$$
\lambda=\left(\lambda_{\text {sat }}-\lambda_{\text {dry }}\right) K_{\mathrm{e}}+\lambda_{\text {dry }}
$$

where $K_{\mathrm{e}}$ (the Kersten number) is a function of the saturation degree $S$ that interpolates thermal conductivity between its maximum $\lambda_{\text {sat }}(S=100)$ and its minimum $\lambda_{\text {dry }}(S=0)$ values. It assumes different expressions depending on the considered model: for Coté \& Konrad (2005) the expression becomes

$$
K_{\mathrm{e}}=\frac{\kappa S}{1+(\kappa-1) S}, \quad \kappa=\left\{\begin{array}{c}
3 \cdot 55, \text { fine sand } \\
4 \cdot 60, \text { coarse sand }
\end{array}\right.
$$

Figure 3 presents the improvement $(I)$ in the $\lambda$ value calculated as follows

$$
I(\%)=\frac{\lambda_{\text {treated }}-\lambda_{\text {untreated }}}{\lambda_{\text {untreated }}}
$$

The obtained values for the MICP-treated sample are compared with the $\lambda$ value of the untreated sand calculated according to the formula by Coté \& Konrad (2005) [equation (4)].

Clearly, the effect of MICP treatment on thermal conductivity is most pronounced for dry conditions. In the 


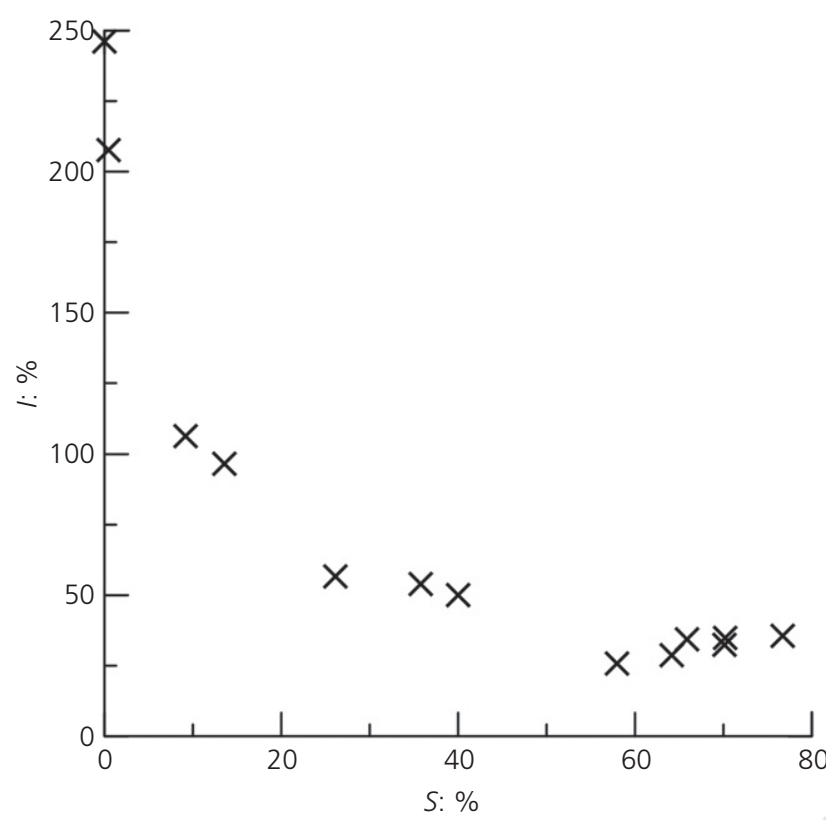

Fig. 3. Improvement in thermal conductivity due to MICP treatment

pendular state $\lambda$ values exhibit significant increase passing from the untreated to the treated state. Changing from dry to saturated conditions the degree of improvement is decreasing, although remaining always at $>25 \%$. The increase in the average value of $\lambda$ has been computed to be $\sim 87 \%$. Moreover, the obtained data show that the improvement in soil thermal conductivity can be quantified as a constant increase of $\sim 0.87 \mathrm{~W} / \mathrm{mK}$ of the $\lambda$ values, corresponding to the untreated sand. A separate line illustrates this in Fig. 2 by modifying equation (3) as follows

$$
\lambda=\left(\lambda_{\text {sat }}-\lambda_{\text {dry }}\right) K_{\mathrm{e}}+\lambda_{\text {dry }}+0.87
$$

where $K_{\mathrm{e}}$ is given by equation (4).

At the pendular state, heat is transmitted through the solid phase through the contact points between the grains. Through SEM observations the calcium carbonate crystals are found to fill the interstitial space increasing the contact among the silica grains. In this case, heat is transmitted not through distinct contact points but through much larger contact areas, equal to the surface area of the calcite crystals

Q9 attached onto the grains. A schematic representation of the above hypothesis is presented in Fig. 4. Figure 5 presents the SEM images obtained for a bio-cemented sample. Here, the interconnection due to calcite bonds between individual grains is observed. The authors use the term 'thermal

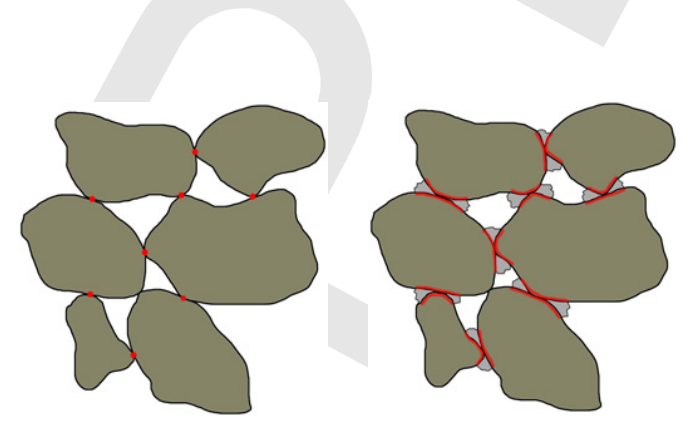

Fig. 4. Left: schematic representation of the contact points between sand grains in the case of untreated sand; right: contact areas due to the presence of calcite crystals bridging the sand particles in the case of MICP-treated sand

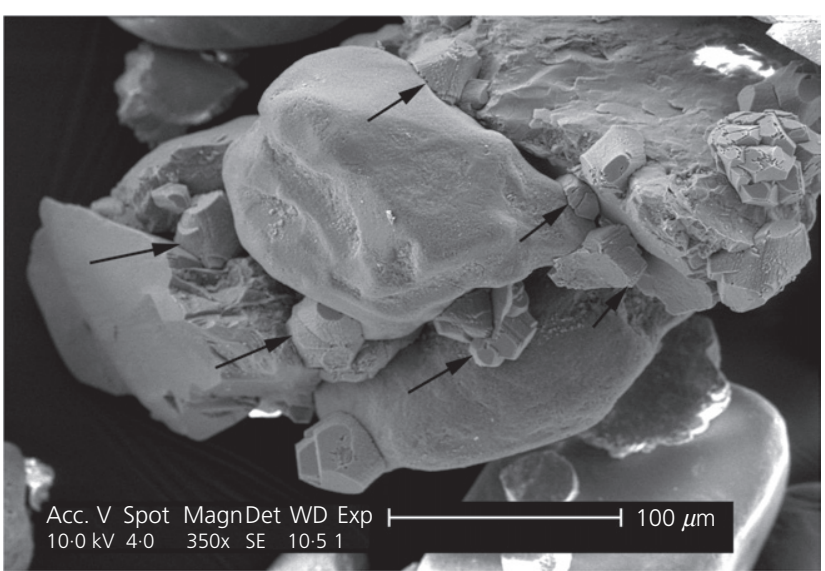

(a)

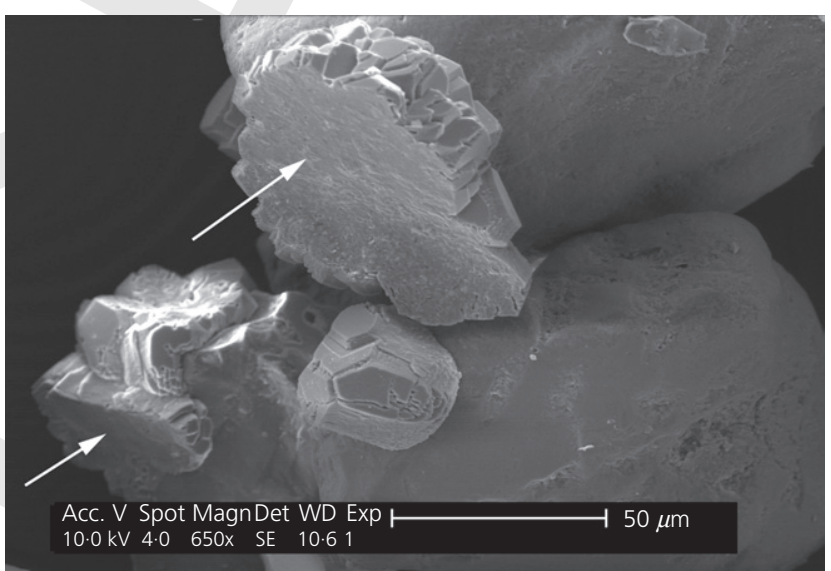

(b)

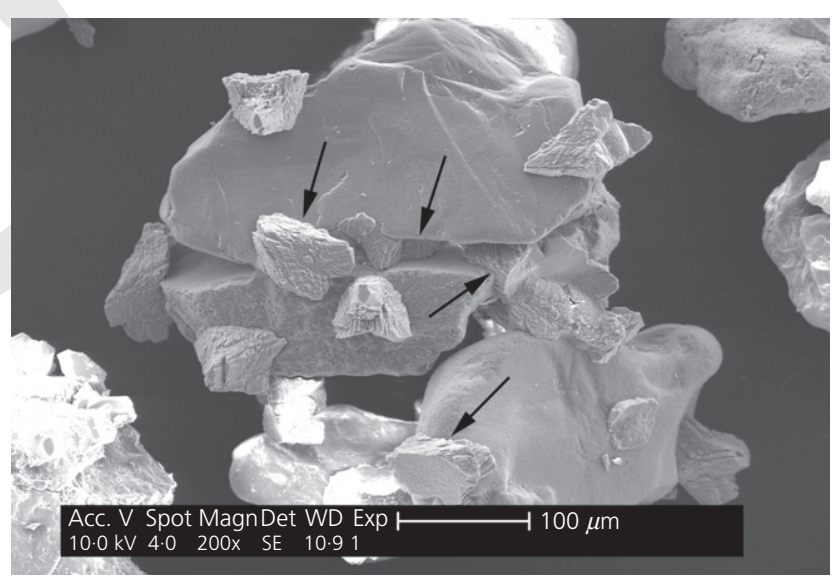

(c)

Fig. 5. SEM images obtained for the MICP-treated material: (a) calcite crystals are found to provide the crucial contact surfaces (arrows); (b) exposed surface of a calcite crystal that grew between two sand grains; and (c) calcite crystals filling the pore space among three neighbouring sand grains

bridges' to highlight exactly the role of the precipitated calcite particles in increasing the energy storage capacity of the soil and providing a much greater soil volume for thermal exchanges between the structure and the surrounding soil.

The distribution of the calcite content was determined as described in the section experimental details. A total of 20 samples were taken as shown in Fig. 6 from the same section of the bio-cemented column. It appears that the calcite distribution is fairly uniform, without any strong 


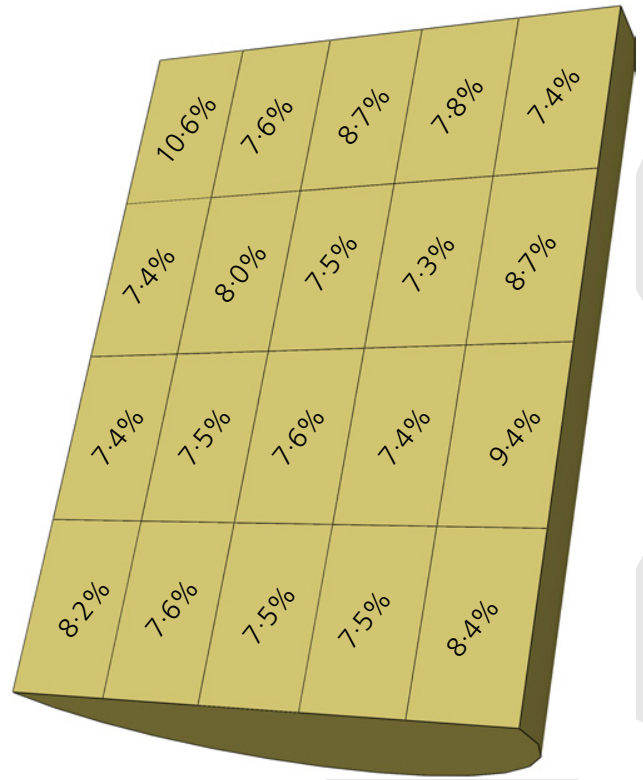

(a)

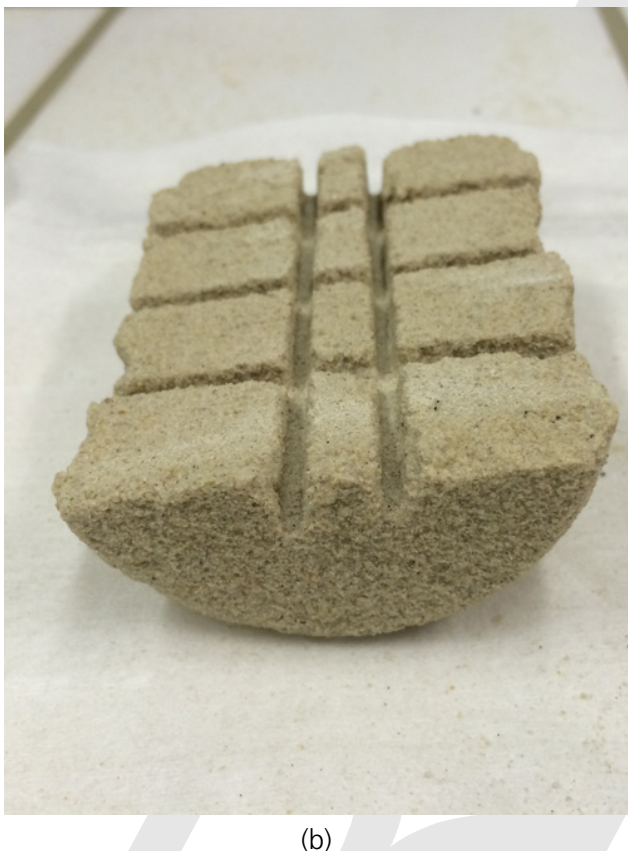

(b)

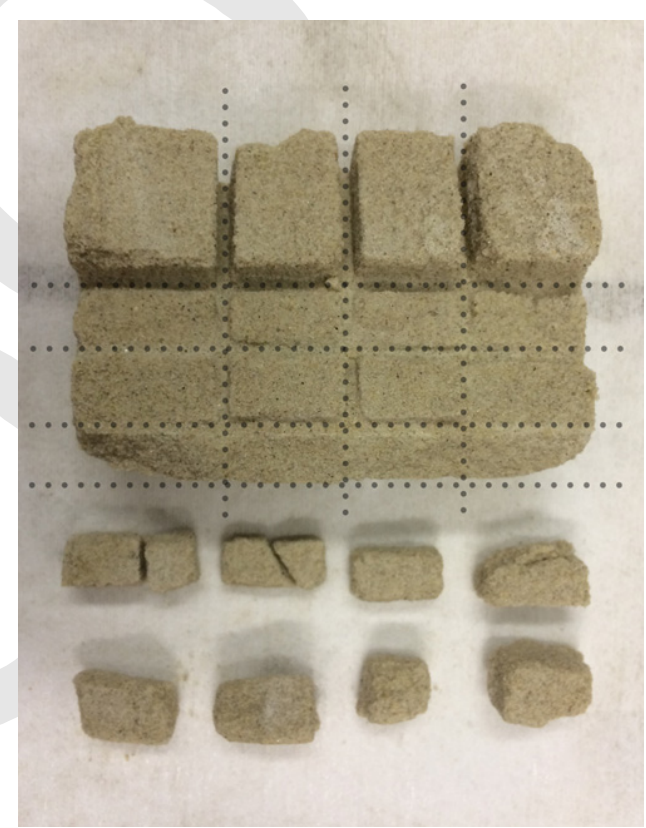

(c)

Fig. 6. (a) Distribution of the calcite content inside the MICP-treated sample expressed as the ratio of the calcite mass over the total dry mass of the sample; (b) and (c) twenty samples are taken from the same section of the cemented column

systematic bias, with slightly higher values at the sides. The average calcite content is found to be equal to $7 \cdot 96 \%(\mathrm{w} / \mathrm{w})$.

\section{CONCLUSIONS}

The effect of MICP treatment results in a strong increase of thermal conductivity of sand at different degrees of saturation. Comparing the thermal conductivity of the bio-treated sand with that of the untreated material shows that the MICP treatment can improve the thermal conductivity of soil by up to $250 \%$. The enhancement is attributed to the formation of calcite crystals, which increases the contact areas between the soil particles and thus improves the heat transfer introducing 'thermal bridges'. MICP can thus offer a potential solution for extending the use of energy piles in areas, where otherwise the environmental conditions would pose restrictions to an efficient heat storage system. A broader range of experiments towards this goal will be reported elsewhere.

\section{REFERENCES}

Akrouch, G., Sánchez, M. \& Briaud, J. (2015). Effect of the unsaturated soil condition on the thermal efficiency of energy piles. In Proceedings of international foundations congress and equipment expo 2015, Dublin, Ireland (eds M. Iskander, M. T. Suleiman, J. B. Anderson \& D. F. Laefer), Geotechnical Special Publication no. 256, pp. 1618-1627. Reston, VA, USA: American Society of Civil Engineers.

Alrtimi, A., Rouainia, M. \& Manning, D. A. C. (2014). An improved steady-state apparatus for measuring thermal conductivity of soils. Int. J. Heat Mass Transf. 72, 630-636.

Amatya, B., Soga, K., Boune-Webb, P., Amis, T. \& Laloui, L. (2012). Thermo-mechanical behaviour of energy piles. 
Géotechnique 62, 503-519, http://dx.doi.org/10.1680/geot.10.P. Q11 116

ASTM (n.d.). ASTM D4373-14: Standard test method for rapid determination of carbonate content of soils. West Conshohocken, PA, USA: ASTM International.

Becker, B., Misra, A. \& Fricke, B. (1992). Development of correlations for soil thermal conductivity. Int. Commun. Heat

Q12 Mass Transf. 19, 59-68.

Bernardi, D., DeJong, J. T., Montoya, B. M. \& Martinez, B. C. (2014). Bio-bricks: biologically cemented sandstone bricks. Constr. Build. Mater. 55, No. 31, 462-469.

Carslaw, H. S. \& Jaeger, J. C. (1959). Conduction of heat in solids. Oxford, UK: Clarendon Press.

Choi, J., Lee, S. R. \& Lee, D. S. (2011). Numerical simulation of vertical ground exchangers: intermittent operation in unsaturated soil conditions. Comput. Geotech. 38, No. 8, 949-958.

Clauser, C. \& Huenges, E. (1995). Thermal conductivity of rocks and minerals. In Rock physics \& phase relations: a handbook of physical constants (eds C. Clauser \& E. Huenges). Washington,

Q14 DC, USA: American Geophysical Union.

Coté, J. \& Konrad, J. M. (2005). A generalized thermal conductivity model for soil and construction materials. Can. Geotech. J. Q15 443-458.

De Jong, J., Soga, K., Burns, S., Van Paassen, L., Qabany, A. Aydilek, A. et al. (2013). Biogeochemical processes and geotechnical applications: progress, opportunities and challenges Géotechnique 63, No. 4, 287-301, http://dx.doi.org/10.1680/geot.

Q16 SIP13.P.017.

Farouki, O. (1981). Thermal properties of soil. Hanover, Germany: CRREL.

Fauriel, S. \& Laloui, L. (2012). A bio-chemo-hydro-mechanical model for microbially induced calcite precipitation in soils.

Q17 Comput. Geotech. 46, 104-120.

Harkes, M., Van Paassen, L., Booster, J., Whiffin, V. \& Van Loosdrechta, M. (2009). Fixation and distribution of bacterial activity in sand to induce carbonate precipitation for ground reinforcement. Ecol. Engng 36, No. 2, 112-117.

$\mathrm{Hu}$, X., Du, J., Lei, S. \& Wang, B. (2001). A model for the thermal conductivity of unconsolidated porous media based on capillary pressure-saturation relation. Int. J. Heat Mass Transf. 44, No. 1, 247-251.

Johansen, O. (1975). Thermal conductivity of soils. Trondheim, Norway: CRREL.

Laloui, L. \& Di Donna, A. (2011). Understanding the thermoQ18 mechanical behaviour of energy piles. Civil Engng 164, 184-191.

Laloui, L. \& Di Donna, A. (2013). In Energy geostructures Q19 (eds L. Laloui \& A. Di Donna). John Wiley \& Sons.
Likos, W. (2014). Pore-scale model for thermal conductivity of unsaturated sand. Geotech. Geol. Engng 33, No. 2, 179-192.

Lu, S., Ren, T. \& Gong, Y. (2007). An improved model for predicting soil thermal conductivity from water content at room temperature. Soil Sci. Soc. Am. J. 71, No. 1, 8-14.

Mortensen, B. \& DeJong, J. (2011). Strength and stiffness of MICP treated sand subjected to various stress paths. In Proceedings of geo-frontiers 2011: advances in geotechnical engineering, Dallas (eds J. Han \& D. E. Alzamora), Geotechnical Special Publication GSP 211, pp. 4012-4020. Reston, VA, USA: ASCE.

Smits, K., Sakaki, T., Lim, A. \& Illangasekare, T. (2009). Determination of the thermal conductivity of sands under varying moisture, drainage/wetting, and porosity conditions applications in near-surface soil moisture distribution analysis. In Proceedings of AGU hydrology days 2009, pp. 57-65.

Smits, K., Sakaki, T., Limsuwat, A. \& Illangasekare, T. (2010). Thermal conductivity of sands under varying moisture and porosity in drainage-wetting cycles. Vadose Zone J. 9, No. 1, 172-180.

Van Paassen, L. A., Harkes, M. P., Van Zwieten, G. A., Van der Zon, W. H., Van der Star, W. R. L. \& Van Loosdrecht, M. C. M. (2009). Scale up of biogrout: a biological ground reinforcement method. In Proceedings of the 17th international conference on soil mechanics and geotechnical engineering, Alexandria, Egypt (eds M. Hamza, M. Shahien \& Y. El-Mossallamy), pp. 2328-2333. Lansdale, PA, USA: IOS Press.

Whiffin, V., Van Passen, L. \& Harkes, M. (2007). Micobial carbonate precipitation as a soil improvement technique. Geomicrobiol. J. 24, No. 5, 417-423.

Woodside, W. \& Messmer, J. (1961). Thermal conductivity of porous media I. Unconsolidated sands. J. Appl. Phys. 32, No. 9, $1688-1699$.

Wu, R., Tinjum, J. \& Likos, W. (2014). Coupling thermal conductivity dry-out curves with unsaturated soil modeling of shallow horizontal geothermal exchange loops. In Proceedings of geo-congress 2014 technical papers@sGeo-characterization and modeling for sustainability (eds A. J. Puppala, P. Bandini, T. C. Sheahan, M. Abu-Farsakh, X. Yu \& L. R. Hoyos), Geotechnical Special Publications 234-235, pp. 4015-4026. ASCE.

Xamán, J., Lira, L. \& Arce, J. (2009). Analysis of the temperature distribution in a guarded hot plate apparatus for measuring thermal conductivity. Appl. Thermal Engng 29, No. 4, 617-623.

Yun, T. \& Santamarina, J. (2007). Fundamental study of thermal conduction in dry soils. Granular Matter 10, No. 3, 197-207.

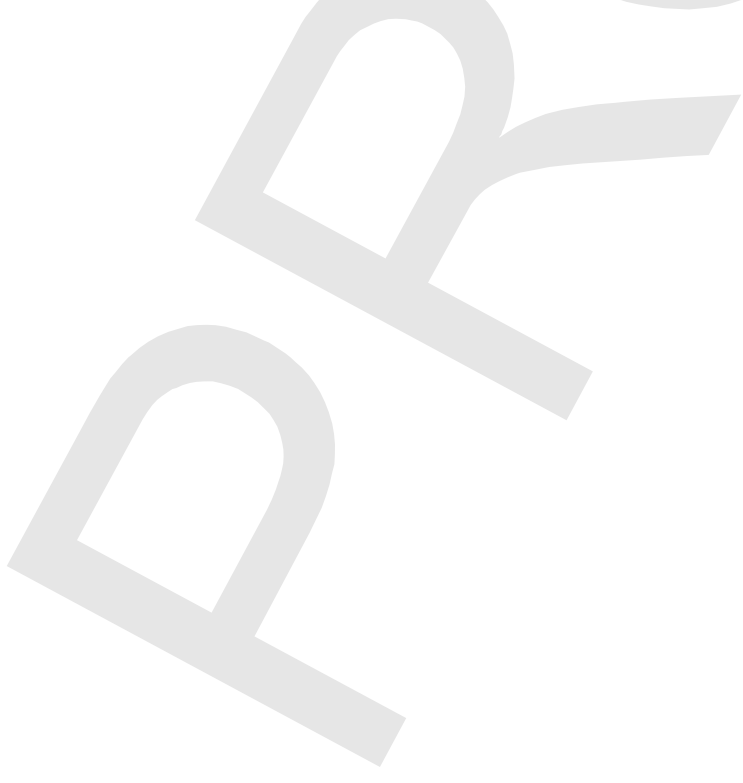

\section{WHAT DO YOU THINK?}

To discuss this paper, please email up to 500 words to the editor at journals@ice.org.uk. Your contribution will be forwarded to the author(s) for a reply and, if considered appropriate by the editorial panel, will be published as a discussion. 


\section{QUERY FORM}

\section{Institution of Civil Engineers (ICE)}

\section{Journal Title: (GEOLETT) Article No: 1500125}

AUTHOR: The following queries have arisen during the editing of your manuscript. Please answer the queries by making the requisite corrections at the appropriate positions in the text.

\begin{tabular}{|c|c|c|}
\hline Query No. & Nature of Query & Author's Response \\
\hline Q1 & $\begin{array}{l}\text { Running title should be not more than } 64 \text { characters including } \\
\text { spaces as per style. Please provide text amendments to reduce } \\
\text { length to } 64 \text { characters. }\end{array}$ & \\
\hline Q2 & $\begin{array}{l}\text { Please provide three keywords from the ICE Proceedings list only } \\
\text { (http://www.icevirtuallibrary.com/pb-assets/for\%20authors/ } \\
\text { ICEEngineeringkeywords.xlsx). }\end{array}$ & \\
\hline Q3 & $\begin{array}{l}\text { Please confirm the deletion made in the sentence 'Soil thermal } \\
\text { conductivity, as understood here, is the...' }\end{array}$ & \\
\hline Q4 & $\begin{array}{l}\text { ASTM } 2487 \text { is not listed in the reference list. Please provide com- } \\
\text { plete details of ASTM } 2487 \text { to insert in the reference list. }\end{array}$ & \\
\hline Q5 & $\begin{array}{l}\text { Please confirm the changes made in the sentence 'This choice } \\
\text { allows comparing the...'. }\end{array}$ & \\
\hline Q6 & $\begin{array}{l}\text { Please confirm the change made from 'cells-forming unit' to } \\
\text { 'colony-forming unit. }\end{array}$ & \\
\hline Q7 & $\begin{array}{l}\text { Please confirm the changes made in the sentence 'No data pre- } \\
\text { cisely corresponding...'. }\end{array}$ & \\
\hline Q8 & $\begin{array}{l}\text { Please confirm the changes made in the sentence 'Having the } \\
\text { lowest standard deviation,...'. }\end{array}$ & \\
\hline Q9 & $\begin{array}{l}\text { Please confirm the changes made in the sentence 'In this case, heat } \\
\text { is transmitted not through...'. }\end{array}$ & \\
\hline Q10 & Please provide the issue number in Alrtimi et al. (2014). & \\
\hline Q11 & Please provide the issue number in Amatya et al. (2012). & \\
\hline Q12 & Please provide the issue number in Becker et al. (1992). & \\
\hline Q13 & $\begin{array}{l}\text { Carslaw and Jaeger (1959) is not cited in the text. Please cite in the } \\
\text { text, else delete from the list. }\end{array}$ & \\
\hline Q14 & $\begin{array}{l}\text { Clauser and Huenges (1995) is not cited in the text. Please cite in } \\
\text { the text and provide page range, else delete from the list. }\end{array}$ & \\
\hline Q15 & $\begin{array}{l}\text { Please provide the volume and issue number in Coté and Konrad } \\
(2005) \text {. }\end{array}$ & \\
\hline Q16 & Please provide all the author names in De Jong et al. (2013). & \\
\hline Q17 & Please provide the issue number in Fauriel and Laloui (2012). & \\
\hline Q18 & Please provide the issue number in Laloui and Di Donna (2011). & \\
\hline Q19 & $\begin{array}{l}\text { Please provide chapter title, page range, publisher location i.e. city/ } \\
\text { town, state (if USA) and country details in Laloui and Di Donna } \\
(2013) \text {. }\end{array}$ & \\
\hline
\end{tabular}


Please provide conference location, editors name, publisher name and location i.e. city/town, state (if USA) and country details in Smits et al. (2009).

Q21 Woodside and Messmer (1961) is not cited in the text. Please cite in the text, else delete from the list. country details in Wu et al. (2014). 